neofilolog

Czasopismo Polskiego Towarzystwa Neofilologicznego

ISSN 1429-2173, 2019, NR 53/1, 129-142

http://dx.doi.org/10.14746/n.2019.53.1.9

http://poltowneo.org/

\title{
Agniesda Jasińska
}

Uniwersytet Pedagogiczny im KEN w Krakowie https://orcid.org/ 0000-0002-4848-1945 agnieszka.jasinska@up.krakow.pl

\section{B1 I CO DALEJ? O KONIECZNOŚCI PRZYGOTOWANIA PROGRAMU NAUCZANIA JĘZYKA POLSKIEGO JAKO OBCEGO DLA CELÓW AKADEMICKICH}

\author{
B1 and what next? On the necessity of developing the program of \\ teaching Polish as a foreign language for academic purposes
}

For the past several years we have been observing a substantial growth of interest in studies in Poland among foreign students, particular those from the East. The required level of language proficiency for Polish universities is B1 which is not difficult to achieve in a year. It is, however, by no means sufficient to participate in university classes, to follow academic discourse, to write papers or prepare for exams. This article presents the results of a research study conducted among academic lecturers and Polish language instructors teaching preparatory classes on the lacks and needs of foreign students. It also presents core demands regarding teaching Polish as a foreign language for academic purposes.

Keywords: level B1, linguistic errors, qualification for studies, academic language, diagnostic tests, postulates of the academic language program

Słowa kluczowe: poziom B1, błędy językowe, kwalifikacja na studia, język akademicki, testy diagnostyczne, propozycje programu języka polskiego dla celów akademickich 


\section{Obcokrajowcy studiujący w Polsce - statystyki, rozwiązania prawne i rzeczywistość akademicka}

Od kilku lat obserwuje się znaczny wzrost zainteresowania obcokrajowców studiami w Polsce. Według raportu ekspertów nauczania języka polskiego jako obcego i drugiego, sporządzonego dla Ministerstwa Nauki i Szkolnictwa Wyższego, w 2015 roku w Polsce studiowało około 46 tysięcy młodych ludzi, zaś dwa lata później już 57 tysięcy ze 157 krajów świata. (M iodunka i in., 2018: 205). Zdecydowana większość studiujących to młodzież ze Wschodu i osoby z polskimi korzeniami.

Zainteresowanie studiami w Polsce to z jednej strony efekt popularności programu Erasmus+,z drugiej - podpisanego w 2015 roku przez M inisterstwo Nauki i Szkolnictwa Wyższego pierwszego Programu Umiędzynarodowienia Szkolnictwa Wyższego. Wprawdzie wzrost do poziomu 4\% (stosunek liczby studentów zagranicznych w Polsce do liczby mieszkańców naszego kraju) wydaje się nie dość zadowalający w porównaniu do średniej w OECD (8\%), to rola programów popularyzujących naukę w Polsce jest bezsporna.

W ramach działań na rzecz umiędzynarodowienia polskiego szkolnictwa wyższego doszło do:

- przygotowania oferty edukacyjnej w języku angielskim;

- przygotowania kursów adaptacyjnych i zajęć z języka polskiego dla przyszłych studentów;

- utworzenia bazy on-line ułatwiającej dostęp do informacji o studiach w Polsce;

- rozbudowania działów rekrutacji obcokrajowców, usprawnienia ich funkcjonowania w celu pozyskiwania większej liczby kandydatów na studia z zagranicy.

Podstawy przyjęcia na studia w języku polskim znajdujemy w $§ 3$ Rozporzqdzenia M inistra Nauki i Szkolnictwa Wyższego z dnia 5 czerwca 2018 roku w sprawie podejmowania przez cudzoziemców studiów i szkoleń oraz ich uczestnictwa w badaniach naukowych i pracach rozwojowych (Dz. U. 2018 poz. 1125). Zgodnie z nimi cudzoziemcy mogą podejmować studia, o których mowa w $§ 1$ ust. 1 pkt 1 i 2, prowadzone w języku polskim, jeżeli spełniają jeden z poniższych warunków:

- ukończyli kurs przygotowawczy do podjęcia kształcenia w języku polskim w jednostkach wyznaczonych przez ministra właściwego do spraw szkolnictwa wyższego lub szkołę ponadpodstawową za granicą, w której zajęcia były prowadzone w języku polskim;

- posiadają certyfikat potwierdzający znajomość języka polskiego co najmniej na poziomie B1 wydany przez Państwową Komisję do spraw 
B1 i co dalej? O konieczności przygotowania programu nauczania języka...

Poświadczania Znajomości Języka Polskiego jako Obcego lub świadectwo dojrzałości wydane w polskim systemie oświaty;

- $\quad$ uzyskali w procesie rekrutacji potwierdzenie uczelni przyjmującej, że ich stopień znajomości języka polskiego pozwala na podjęcie studiów. Rozporządzenie to zastąpiło wcześniejsze przepisy z 2006 roku, które umożliwiały podjęcie studiów osobom znającym język polski na poziomie B2. Oznacza to, że wymagania dla przyszłych studentów zostały obniżone, co w istocie rzeczy stanowi jeszcze większe utrudnienie dla wykładowców, lektorów i samych kandydatów na studia. Już wcześniej bowiem nauczyciele akademiccy sygnalizowali, że poziom językowy cudzoziemskich kandydatów nie jest wystarczający, by mogli uczestniczyć w dyskursie akademickim ${ }^{1}$.

Obecnie sytuacja jest jeszcze trudniejsza: kandydaci cudzoziemscy przyjmowani są na studia na podstawie zaświadczeń o poziomie znajomości języka, które często nie są w żaden sposób weryfikowane przez władze i uczelnie polskie. Zaświadczenia te pochodzą z kraju przyszłego studenta, najczęściej z byłego Związku Radzieckiego. Wielu kandydatów jest też przyjmowanych na uniwersytety na podstawie Karty Polaka. W pierwszym przypadku uczelnie otrzymują zaświadczenia wydawane przez placówki, które nie posiadają kompetencji ani kwalifikacji do wydawania zaświadczeń o poziomie znajomości języka; przypadek drugi, czyli Karta Polaka, także nie stanowi dow odu na znajomość języka polskiego, gdyż kryteria jej przyznania wynikają z faktu, że kandydat ma polskie pochodzenie i pewną znajomość polskiej kultury i historii. Opanowanie języka podczas egzaminu na Kartę Polaka nie jest dostatecznie weryfikowane. W efekcie na uniwersytety trafiają osoby, które nierzadko znają język polski na poziomie $A 2$, a nawet na $A 1$. Wielu studentów rezygnuje z nauki po pierwszym roku studiów z powodu niedostatecznego opanowania języka polskiego. Inni przez całe studia borykają się z problemami językowymi².

\footnotetext{
${ }^{1}$ W raporcie o wyzwaniach polityki językowej W.T. M iodunka w 2012 roku sygnalizował, że punkt 3 mówiący o warunku przyjęcia na studia na podstawie „uzyskania potwierdzenia uczelni przyjmującej" bez żadnych kryteriów ze strony M NiSW daje wolną rękę uczelniom mało doświadczonym w kształceniu cudzoziemców do uznaniowego potwierdzania stopnia znajomości polskiego i do różnego rodzaju nadużyć (Dąbrowska, Miodunka, Pawłowski, 2012: 40).

${ }^{2}$ Wykładowcy sygnalizują, że osoby przyjmowane na studia popełniają tak liczne błędy, że wymusza to konieczność poprawiania prac zaliczeniowych i dyplomowych nie tylko pod względem merytorycznym, lecz także językowym.
} 


\section{W stronę przygotowania programu do nauczania języka polskiego dla celów akademickich}

Powyższe dane pokazują, że istnieje pilna potrzeba opracowania programów nauczania języka polskiego dla celów akademickich. Autorka artykułu podjęła więc następujące działania wstępne, by program taki mógł powstać. Były to:

- badanie fokusowe wśród nauczycieli jezzyka polskiego na kursach przygotowujących do studiów w Polsce po polsku oraz wśród nauczycieli akademickich;

- $\quad$ badania ankietowe wśród nauczycieli języka polskiego i nauczycieli akademickich dotyczące największych problemów studentów zagranicznych, którzy studiują po polsku (przeprowadzone na Uniwersytecie Pedagogicznym, Uniwersytecie Ekonomicznym, Politechnice Krakowskiej i Uniwersytecie Rzeszowskim; wszystkie te placówki przyjmują z roku na rok coraz więcej obcokrajowców, którzy decydują się na studia po polsku);

- przeprowadzenie testu diagnostycznego określającego poziom znajomości języka polskiego przez kandydatów na studia w Polsce i osoby już studiujące na pierwszych latach; miał on wskazać braki językowe utrudniające lub uniemożliwiające studiowanie.

Pierwszy krok pozwolił określić podstawowe potrzeby i bolączki nauczycieli polskiego oraz nauczycieli akademickich, a także sformułować pytania do ankiety o dużo większym zasięgu. W badaniu fokusowym wzięło udział 12 nauczycieli z Uniwersytetu Pedagogicznego (byli to zarówno nauczyciele języka polskiego jako obcego, jak i wykładowcy akademiccy, którzy na co dzień pracują z obcokrajowcami i zgłaszają problemy językowe swoich podopiecznych). Zorganizowano je zgodnie z zasadami przeprowadzania wywiadów grupowych (jakościowych) w badaniach terenowych (Babbie, 2013: 345). Na podstawie notatek z wywiadów opracowano pytania do ankiety ${ }^{3}$ (zob. Wilczyńska, M ichońska-Stadnik, 2010: 167-173) mającej na celu ocenę językowych kompetencji komunikacyjnych i gotowości do podjęcia studiów przez studentów zagranicznych w Polsce. Wzięło w niej udział 28 osób: $70 \%$ badanych to lektorzy języka polskiego jako obcego pracujący na uczelniach (Uniwersytet Pedagogiczny w Krakowie, Uniwersytet Ekonomiczny w Krakowie, Politechnika Krakowska, Uniwersytet Rzeszowski), pozostałe $30 \%$ to nauczyciele akademiccy z kierunków takich jak: geografia i turystyka (2 osoby), ekonomia (1 osoba), architektura (1 osoba), politologia (1 osoba), nauki polityczne (1 osoba), sztuki wizualne (1 osoba).

${ }^{3}$ Zopcją wybór wielokrotny. 
B1 i co dalej? O konieczności przygotowania programu nauczania języka...

Zdecydowana większość nauczycieli języka polskiego i nauczycieli akademickich oceniła znajomość polszczyzny studentów zagranicznych jako niedostateczną, uniemożliwiającą im swobodne posługiwanie się dyskursem akademickim w mowie, a zwłaszcza w piśmie. Tylko 3,8\% badanych było zadowolonych z poziomu kompetencji w polszczyźnie swoich podopiecznych. Kilku uczących $(7,7 \%)$ wręcz stwierdziło, że zagraniczni studenci o tak niskich umiejętnościach nie powinni w ogóle być dopuszczeni do studiowania. Pozostali badani byli mniej kategoryczni: 34\% było zdania, że znajomość języka jest wystarczająca na początku nauki, ale wymaga doskonalenia podczas całego okresu studiów; 53,8\% natomiast, że nie jest ona na początku wystarczająca, lecz można ją systematycznie doskonalić, najlepiej podczas specjalnych kursów językowych.

Jako największy problem w nauczaniu obcokrajowców badani wskazali niedostatki w kompetencji gramatycznej i leksykalno-semantycznej będące nierzadko pokłosiem negatywnego transferu z języka ojczystego oraz błędy na poziomie łączliw ości semantyczno-syntaktycznej wynikające z korzystania z translatorów internetowych typu „google translate” (57,7\% badanych). 46\% nauczycieli jako źródło problemów w nauce wskazało różnice kulturowe, 42,3\% dostrzegło błędy związane z niestosownością socjolingwistyczną wypowiedzi ustnych i pisemnych zagranicznych studentów, a 38\% oceniło negatywnie poziom ich prac pisemnych. Należy też odnotować, że aż $23 \%$ respondentów jako powód niepowodzeń w nauce wskazało problemy osobiste studentów wiążące się ze słabą adaptacją do nowych warunków życia za granicą, rozłąką z rodziną itp. ${ }^{4}$

Diagnoza nauczycieli znalazła potwierdzenie w teście językowym przeprowadzonym w grupach obcokrajowców na kursach przygotowawczych i lektoratach języka polskiego na studiach wyższych. Badani, studenci trzech uczelni krakowskich (Uniwersytet Pedagogiczny, Politechnika Krakowska, Uniwersytet Ekonomiczny), napisali test diagnostyczny ${ }^{5}$ zawierający zadania badające kompetencję gramatyczno-syntaktyczną i sprawność pisania. Test był przeprowadzony w czerwcu 2018 roku, a więc pod koniec roku akademickiego, kiedy kurs przygotowaw czy dobiegał końca. Należało więc spodziewać się wśród dużej części uczących się, którzy brali w nim udział, poziomu umożliwiającego im podjęcie studiów. Test przeprowadzono w grupie 130 osób, głównie z Ukrainy i Białorusi.

Wszyscy zdający otrzymali ocenę pozytywną: zarówno ci, którzy uczestniczyli w kursie przygotowawczym, jaki ci, którzy już studiowali na pierwszym roku. Trzeba jednak zaznaczyć, że test zawierał zadania z poziomu B1 i częściowo B2 (zob. Janowska i in., 2016: 71-139), który umożliwia co prawda podjęcie studiów w Polsce, ale,

\footnotetext{
${ }^{4}$ Należy pamiętać, że część studentów z Ukrainy pochodzi z terenów objętych wojną, ich pobyt w Polsce jest więc wymuszony przez sytuację polityczną.

${ }^{5}$ Skupiający się na ustaleniu deficytów językowych.
} 
zgodnie z opiniami nauczycieli, nie daje gwarancji na ich kontynuację i ukończenie ze względu na niedostateczną znajomość języka. W pracach powtarzały się błędy opisane już w literaturze przedmiotu (zob. np. Dąbrowska, 2004; Dąbrowska, Pasieka, 2005; Krawczuk, 2008; Izdebska-Długosz, 2014). Należą do nich:

- $\quad$ błędy związane z interferencją rodzajową, czyli z nieprawidłowym rozpoznaniem rodzaju gramatycznego w polszczyźnie (np. polskie nijakie 'muzeum' to w rosyjskim męski 'muzjej', 'stypendium' to rosyjska żeńska 'stipemndija'), a co za tym idzie nieprawidłowa odmiana;

- błędy związane z brakiem rozpoznania rodzaju męsko- i niemęskoosobowego w języku polskim, co skutkuje następującymi zdaniami: *Dzieci byli w szkole, *Stoły byli nakryte, Oni byli przygotowane na gości, *Pacjenty, które byli w przychodni;

- nieprawidłowa odmiana rzeczowników męskoosobowych: *Studenty z Ukrainy, *Bohatery tego opowiadania;

- błędy związane z interferencją form przypadków: *Poznałem tych dziewczyn, gdzie przenosi się model rosyjskiego biernika liczby mnogiej równego dopełniaczowi, a także *Student tego uniwersyteta, gdzie także przenosi się jedyną w rosyjskim końcówkę dopełniacza do polszczyzny dysponującej dwiema równoległymi -a i -u, *Pracuję nauczycielem, czyli narzędnik zamiast mianownika, * Lubię muzyku, czyli rosyjska końcówka biernika rodzaju żeńskiego zamiast polskiej nosowej ę itp.;

- błędy związane z przenoszeniem wzorów fleksji czasownikowej z rosyjskiego do polszczyzny, np. nieużywanie końcówek osobowych w czasie przeszłym *Ja był, *ja napisała lub z nieprawidłowym ich opanowaniem np. *Gdyby ja byłem;

- błędy związane z przenoszeniem znaków z cyrylicy do alfabetu łacińskiego * esteśmy, *mysiał to zrobić;

- błędy składniowe typu: *U niej potrzeba poznania polskiej kultury;

- błędy związane ze stosownością socjolingwistyczną, takie jak: *Wy dostaliście mój mail zamiast Pani dostała mój mail, czy też * Serdeczne życzenia, zamiast Pozdrawiam lub Z poważaniem.

Co ciekawe, wymienione wyżej błędy rzadko pojawiały się w komponencie gramatycznym testu, a głównie w części poświęconej sprawdzeniu stopnia opanowania sprawności pisania. Wygląda więcna to, że o ile studenci dobrze rozwiązują zadania gramatyczne zawierające polecenia typu: Proszę wstawić odpowiedniq̨ formę rzeczownika/czasownika w nawiasie, o tyle tracą kontrolę nad formami gramatycznymi w ćwiczeniach ukierunkowanych na sprawności językowe ${ }^{6}$. Jest to istotna

${ }^{6}$ Podobne zjawisko obserwuje się podczas rozmów kwalifikacyjnych lub egzaminów ustnych. 
informacja dla wszystkich nauczycieli języka polskiego, gdyż, jak wiadomo, w całym toku uniwersyteckiej edukacji studenci nie są rozliczani z ćwiczeń gramatycznych, lecz z wypowiedzi pisemnych. Koncentracja na treści powodująca 'zapominanie' o poprawności jest przejawem niskiego stopnia zinternalizowania struktur.

Zebrane informacje pozwoliły autorce artykułu na stworzenie wraz z M ałgorzatą Jasińską-Panek wstępnej propozycji programu nauczania studentów przygotowujących się do studiów w Polsce lub dla studentów pierwszych lat. Program ten jest realizowany w Studium Nauki Języka Polskiego Uniwersytetu Pedagogicznego w ramach kursów przygotowawczych do studiów w Polsce. Ze względu na wielkość przedsięwzięcia kolejne etapy prac wymagają współpracy większej liczby lektorów i wykładowców zarówno z Uniwersytetu Pedagogicznego (z Instytutu Filologii Polskiej i kierunków przyjmujących obcokrajowców np. turystyki, politologii i nauk społecznych), jak i z innych uczelni prowadzących zajęcia z języka polskiego akademickiego i języków specjalistycznych, w szczególności z Uniwersytetu Ekonomicznego i Politechniki Krakowskiej.

Program ten opiera się na trzech filarach:

1. podnoszenie językowych kompetencji komunikacyjnych kandydatów na studia, deklarowany poziom B1 jest bowiem zbyt niski, by mogli efektywnie studiować po polsku;

2. podnoszenie językowych kompetencji komunikacyjnych w ramach języka akademickiego, zawierającego elementy stylistyki praktycznej, zagadnień poprawnościowych, w oparciu o stosowną literaturę przedmiotu (przeznaczoną dla studentów cudzoziemskich i polskich);

3. zajęcia ze słownictwa specjalistycznego z dziedziny, którą kandydat planuje studiować.

Te założenia w odniesieniu do przyszłych studentów w obecnej sytuacji akademickiej wydają się trudne do zrealizowania, żadna z uczelni nie prowadzi bowiem tak zwanego „roku zerowego”, czyli bezpłatnych kursów przygotowawczych dla kandydatów na studia. Wszystkie zajęcia w ramach roku przejściowego mają charakter komercyjny, co znacznie utrudnia do nich dostęp osobom mniej zamożnym. Sytuacja osób już studiujących wygląda niewiele lepiej. Lektoraty języka polskiego powstają na prośbę konkretnych wydziałów, ich liczba godzin jest zmienna, podobnie jest z liczbą semestrów: zależy ona od konkretnego 'zamówienia' ze strony jednostki, w której studiuje duża liczba obcokrajow ców. Nie ma rozwiązań systemowych, które umożliwiłyby w drożenie jednolitego, konsekwentnego programu języka polskiego dla celów akademickich. Te faktycznie realizowane w grupach cudzoziemskich w danej jednostce uzależnione są od bieżących potrzeb: lektorzy sygnalizują np. niski poziom kompetencji studiujących i poświęcają całą pulę godzin na podnoszenie poziomu 
znajomości języka ogólnego. I na tym przygotowanie do studiowania po polsku się kończy. Z językiem akademickim czy specjalistycznym, związanym ze studiowaną dziedziną, studenci muszą często radzić sobie sami.

Konieczność wypracowania rozwiązań systemowych wydaje się bezsprzeczna, liczba studiujących obcokrajowców będzie się bowiem zwiększać, a problem ich niedostosowania językowego narastać.

\section{Podnoszenie językowych kompetencji komunikacyjnych kandydatów na studia}

Najbardziej realny do wdrożenia wydaje się postulat pierwszy, czyli podnoszenie językowych kompetencji komunikacyjnych uczących się polskiego. $\mathrm{Na}$ rynku istnieje już bogata i zróżnicowana oferta podręcznikowa do języka polskiego jako obcego dla poszczególnych poziomów. Najbardziej znane pozycje dla poziomu B2 to: Słownictwo polskie w ćwiczeniach dla obcokrajowców (Seretny, 2016), Przygoda z gramatykq (Pyzik, 2018), Co z czym? (M ędak, 2014), a także, Pisać jak z nut (Lipińska, Dąmbska, 2016). Dobrą pomoc stanowi podręcznik Wśród ludzi i ich spraw, (Bajor, Madej, 2012), gdzie autorki proponują zestaw tekstów o tematyce przybliżającej realia studiowania w Polsce lub ukierunkowujących na określone dziedziny nauki. Oprócz tekstów podręcznik zawiera wiele ćwiczeń gramatycznych, leksykalnych, a także związanych z rozwijaniem sprawności pisania. Niezwykle istotne wydają się zadania dotyczące synonimii składniowej umożliwiające studentom wzbogacanie języka. Podręcznik ten to doskonały pomost między nauczaniem języka ogólnego i akademickiego. Inną pozycją jest opracowanie autorstwa Ciesielskiej-M usameh, Guziuk-Świcy i Przechodzkiej Z polskim w świat (2018). Autorki sygnalizują we wstępie, że podręcznik może być wykorzystywany na rocznych kursach przygotowujących do studiów w Polsce. Jest to bardzo dobra pomoc językowa dla studentów ze Wschodu (zawiera sporo materiału uwrażliwiającego na interferencję z języków wschodniosłowiańskich).

\section{Podnoszenie językowych kompetencji komunikacyjnych w ramach zajęć z języka polskiego akademickiego}

Oferta wydawnicza do nauki polszczyzny akademickiej jest jeszcze bardzo uboga, choć poszczególne ośrodki podejmują próby redagowania materiałów ukierunkowanych na jej rozwijanie. Na rynku pojawiła się ostatnio pozycja (Nie)codzienny język polski (Tambor, 2018) o którym sama autorka pisze, że to podręcznik dla osób planujących studia w Polsce, choć przeznaczony jest do nauki podczas kursów krótkich. Wzbogacanie oferty jest więc koniecznością i powinno przebiegać dwutorowo. Zjednej strony należy zbudować korpusy tekstów w oparciu 
o dane pozyskane z poszczególnych instytutów, w których najchętniej studiują cudzoziemcy $^{7}$; z drugiej zaś, korzystać z materiałów umożliwiających budowanie kompetencji językowych w oparciu o inwentarze dotyczące języka akademickiego i stylistykę praktyczną adresowane do studentów polskich. Warto zapoznać się z takimi wydawnictwami, jak: Formy i normy, czyli poprawna polszczyzna w praktyce (M osiołek-Kłosińska, red., 2014) oraz Polszczyzna na co dzień (Bańko, red., 2013).

Na poziomie technik nauczania niezwykle pożądane jest wdrożenie w grupach uczących się strategii, które umożliwiają pracę samodzielną, umiejętność przetwarzania tekstów dla celów naukowych, badawczych, poznawczych, a więc takich, które związane są ze studiowaniem. Z pomocą w realizacji ostatniego z tych celów przychodzi Europejski system opisu kształcenia językowego (2003) (dalej: ESOKJ), w którego uzupełnieniu z 2018 roku znacznie rozszerzono opis działań mediacyjnych. Do tej pory mediacja jako umiejętność przetwarzania tekstu była częścią „Działań komunikacyjnych i strategii językowych”, a w jej opisie znajdowały się takie elementy, jak: tłumaczenia symultaniczne i konsekutywne oraz nieformalne działania w sytuacjach np. towarzyskich i transakcyjnych (np. podczas zakupów z członkami rodziny i znajomymi). Przy mediacji pisemnej zaznaczono, że wiąże się ona z dokładnym tłumaczeniem różnego rodzaju tekstów literackich, naukowych, kontraktów, tekstów prawniczych, ale też z ich streszczaniem i parafrazowaniem (ESOKJ , 2003: 83). W rozszerzonym opisie ESOKJ autorzy wyróżniają trzy typy działań związanych z mediacją. Są to: mediacja tekstowa, pojęciowa i komunikacyjna ${ }^{9}$ (CEFR. Companion Volume with New Descriptors, 2018: 106). M ediacja tekstowa polega na przekazywaniu przez użytkowników języka informacji w formie ustnej i pisemnej, objaśnianiu danych, przetwarzaniu tekstu mówionego i pisanego, tłumaczeniu pisemnym i ustnym, tworzeniu notatek, wyrażaniu opinii na temat tekstu (w tym także literackiego) oraz jego krytycznej analizie. M ediacja pojęciowa łączy się z zadaniami umożliwiającymi współpracę w grupie w zakresie np. tworzenia znaczeń. Natomiast mediacja komunikacyjna rozumiana jest jako proces tworzenia przestrzeni wielokulturowej, pośredniczenie w nieformalnych sytuacjach, na przykład pomiędzy rówieśnikami, a także ułatwianie porozumienia w sytuacjach delikatnych i konfliktowych.

\footnotetext{
${ }^{7}$ W przypadku Uniwersytetu Pedagogicznego najczęściej wybieranymi kierunkami są turystyka, politologia, pedagogika oraz kierunki artystyczne, w Uniwersytecie Ekonomicznym - stosunki międzynarodowe i turystyka, zaś na Politechnice Krakowskiej największą popularnością cieszą się architektura, informatyka i ekonomia.

${ }^{8}$ Common European Framework of Reference for Languages: Learning, Teaching, Assessment. Companion Volume with New Descriptors (2018), Strasbourg: Council of Europe.

9 Tłumaczone terminy pochodzą z artykułu M artyniuka (2018).
} 
M ediacja tekstowa w sposób naturalny jest częścią aktywności akademickiej studenta, zarówno polskiego, jak i cudzoziemskiego. Przetwarzanie tekstów jest nieodłączną częścią studiowania, dlatego rozwijanie tej umiejętności podczas przygotowawczych kursów językowych wydaje się niezbędne. Zarówno tłumaczenie, jak i streszczanie czy parafrazowanie wpisują się w inwentarz podstawowych strategii zdobywania wiedzy stosowanych przez studentów każdego kierunku. Przygotowanie kandydatów do studiowania poprzez budowanie akademickich umiejętności pracy z tekstem stanowi ważne, choć niezwykle ambitne wyzwanie dla nauczycieli języka polskiego. Jednym z celów przyszłych autorów pomocy dydaktycznych dla osób rozpoczynających studia powinno być włączenie do klasycznego układu podręcznika, w którym ćwiczy się podsystemy języka (gramatykę, słownictwo, wymowę i pisownię) i rozwija sprawności (rozumienie tekstu, rozumienie ze słuchu, pisanie i mówienie) zadań umożliwiających podejmowanie działań mediacyjnych. I tak na przykład, w rozwijaniu mediacji tekstowej, oprócz standardowego polecenia typu: Proszę powiedzieć, czy informacje poniżej sq prawdziwe, czy nie, albo Proszę odpowiedzieć na pytania poniżej, pod tekstem powinny się też znaleźć ćwiczenia typu: Proszę streścić tekst w 10 zdaniach, Proszę opowiedzieć tę historię z punktu widzenia jednego z bohaterów, Proszę zrelacjonować wydarzenia opisane w tekście profesorowi/przełożonemu, Na podstawie przeczytanego tekstu proszę napisać oficjalne pismo/raport/sprawozdanie/opinię do... itp.

Dwa pozostałe rodzaje mediacji - pojęciowa i komunikacyjna, szczególnie akcentowane w rozszerzonej wersji Europejskiego systemu opisu kształcenia językowego nabierają nowego znaczenia w sytuacji internacjonalizacji placówek edukacyjnych. W każdej uczelni mamy coraz więcej obcokrajowców, co oznacza więcej sytuacji zderzenia kultur, zadania mediacyjne stosowane podczas lekcji języka polskiego mogą więc odegrać niebagatelną rolę w zmniejszaniu dystansu i porozumieniu ponad podziałami. „Obserwując kontakty i rozmowy między ludźmi w różnych sektorach życia społecznego, możemy z łatwością stwierdzić, że mediacja (językowa, kulturowa i społeczna) staje się zjawiskiem coraz bardziej powszechnym. W wielojęzycznych i wielokulturowych społeczeństwach nie jest to działanie zarezerwowane wyłącznie dla specjalistów czy ograniczonej grupy użytkowników języka (np. tłumaczy), ale stanowi jedną z podstawowych form komunikacji przedstawicieli różnych środowisk. Jest to element codziennej, naturalnej i spontanicznej komunikacji i odpowiada chęci wzajemnego porozumienia na wielu płaszczyznach" (Janowska, 2017: 83).

M etodyka nauczania języków obcych, w tym języka polskiego jako obcego, dysponuje dużą i zróżnicowaną gamą technik pracy, za pomocą których można realizować zadania związane z tworzeniem znaczeń, a także przyjaznej przestrzeni wielokulturowej. Wystarczy ukierunkować standardowe zadania 
słownikowe na wspólne odkrywanie i interpretację słów i zwrotów w grupie obcokrajowców pochodzących z różnych obszarów kulturowych i otrzymamy sytuację, w której dochodzi do swoistej wymiany myśli i negocjowania znaczeń. Począwszy od sytuacji codziennych (praca, rutyna dnia codziennego, pory posiłków, tradycje rodzinne, role społeczne), aż po kulturę pisaną wielką literą, elementy historii, polityki, języka wartości i pojęć aksjologicznych (patriotyzm, wolność, honor itp.).

W ramach zadań rozwijających sprawność mówienia warto skorzystać z technik, które umożliwią mediację komunikacyjną. Jedna z nich to tzw. role play, gdzie uczący się mogą wcielać się w osoby z innego obszaru kulturowego, co umożliwi im spojrzenie na dany problem z innej perspektywy.

Poszerzaniu horyzontów służą też zadania konwersacyjne ukierunkowane na zrozumienie Innego, np. symulacja dyskusji oxfordzkiej, czy zadanie typu: Daj mi cztery minuty i nie przerywaj mi. Podobne zadania związane $z$ „wchodzeniem w skórę innej osoby" można wykonać pisemnie. Warto rozwijać te formy wypowiedzi, które znajdują się w programie kursu, a które umożliwiają uczącym się poszerzanie horyzontów. Są to bez wątpienia: tekst argumentacyjny, relacjonowanie wypowiedzi innych, opowiadanie z punktu widzenia bo hatera $x$, a także rozmaite teksty okolicznościowe, mniej lub bardziej formalne, które są nośnikiem danej kultury zarówno w warstwie socjolingwistycznej, jak i socjokulturowej.

\section{Nauczanie słownictwa specjalistycznego}

Ostatnim postulatem związanym z rozwijaniem kompetencji umożliwiających studiowanie w Polsce po polsku jest sformalizowanie nauczania języka polskiego specjalistycznego, a więc zajęcia propedeutyczne. Niektóre uczelnie realizują już autorskie programy nauczania na przykład języka ekonomicznego, technicznego, medycznego. Na Politechnice Krakowskiej kandydaci na studia ekonomiczne, techniczne lub medyczne mają do dyspozycji zarówno zajęcia z języka polskiego ogólnego (liczba zależy od poziomu zaawansowania językowego przyszłego studenta), jak i dodatkowe godziny słownictwa specjalistycznego oraz zajęć z przedmiotów kierunkowych. Dla przykładu: przyszły student ekonomii będący na poziomie A1 ma w programie 600 godzin języka polskiego ogólnego i 180 godzin zajęć kierunkowych obejmujących polski język ekonomiczny, prawniczy, a także matematykę i informatykę dla ekonomistów. Zajęcia z języka specjalistycznego w połączeniu z przedmiotami kierunkowymi po polsku prowadzi się także na Uniwersytecie Łódzkim: kandydaci na studia mają do dyspozycji około 500-600 godzin języka polskiego ogólnego i 300 godzin języka specjalistycznego wraz z udziałem w zajęciach kierunkowych. Nieco inny model proponuje Uniwersytet Ekonomiczny: kurs przygotowawczy obejmuje tam 480 
godzin języka polskiego ogólnego, 60 godzin języka ekonomicznego oraz 60 godzin matematyki w języku polskim. W każdym z proponowanych rozwiązań proporcje języka ogólnego w stosunku do specjalistycznego są inne, każda z uczelni podejmuje bowiem w tej kwestii autonomiczną decyzję. Za przykład niech posłużą ponownie Politechnika Krakowska i Uniwersytet Ekonomiczny. Pierwsza z uczelni ma sporą liczbę godzin zajęć z języka polskiego specjalistycznego, proponuje też więcej przedmiotów kierunkowych. Uniwersytet Ekonomiczny natomiast ma w programie propedeutycznym tylko zajęcia z matematyki, ale w ramach języka polskiego ekonomicznego oferuje przygotowanie do wszystkich kierunków na studiach ekonomicznych. Kandydat poznaje więc słownictwo z makro i mikroekonomii, a także prawa, finansów, zarządzania i statystyki.

Dobór materiałów do nauki języka specjalistycznego to także niezależna decyzja każdej z placówek. Niektóre z nich posiadają w swojej ofercie propozycje podręcznikowe, inne zaś tworzą własne autorskie materiały w oparciu o dostępne na rynku publikacje z danej dziedziny. Podstawowe podręczniki do nauki języka polskiego specjalistycznego dla przyszłych studentów to: Anatomia, język specjalistyczny (Gałat, 2018), Wybraliśmy ekonomię (Kugiel-Abuhasna, 2017), Chcę studiować medycynę (Podsiadły, Lechowicz, 2004), Matematyka po polsku (Wróbel, Zielińska, Rudziński, 2014), Podstawy cytologii (Kaźmierczak, Gosztowt, 2012). Oferta podręczników do języków specjalistycznych jest z roku na rok coraz bogatsza, zważywszy jednak na zapotrzebowanie, należy przemyśleć jej poszerzenie. Zanim to nastąpi, konieczne są kroki prowadzące do prawidłowego nakreślenia profilu odbiorcy oraz analiza jego potrzeb. Kroki te wydają się konieczne ze względu na różnorodność i specyfikę potrzeb osób planujących naukę języka specjalistycznego.

\section{Podsumowanie}

Program nauczania języka polskiego specjalistycznego, podobnie jak program języka akademickiego powinien doczekać się rozwiązań systemowych, co oznaczało by w pierwszej kolejności ustalenie standardów godzinowych i programowych dla wszystkich uczelni i poszczególnych specjalności. W ostatnim roku Narodowa Agencja Wymiany Akademickiej zwróciła się do przedstawicieli uczelni oferujących zajęcia z języków specjalistycznych z prośbą o zaproponowanie standardu nauczania dla celów akademickich i specyficznych. W wyniku konsultacji z przedstawicielami Politechniki Krakowskiej, Politechniki Wrocławskiej, Uniwersytetu Łódzkiego, Uniwersytetu Rzeszowskiego, Uniwersytetu Warszawskiego, Katolickiego Uniwersytetu Lubelskiego i Uniwersytetu im. M ikołaja Kopernika w Toruniu opracowano wstępne ramy godzinowe i programowe ję- 
B1 i co dalej? O konieczności przygotowania programu nauczania języka...

zyka polskiego dla kandydatów na studia w Polsce. Wyżej wymienione placówki rozpoczną nauczanie języka polskiego dla celów akademickich i specjalistycznych według wspólnie wypracowanych kryteriów w roku akademickim 2019/2020. Perspektywa wprowadzenia nowych standardów dotyczących nauczania języka polskiego dla kandydatów na studia w Polsce umożliwi rozpoczęcie prac nad programami języka polskiego adresowanymi do tej grupy odbiorców. Ze względu na obszerność i zróżnicowanie zagadnienia projekt ten wymaga jednak współpracy wielu podmiotów.

\section{BIBLIOGRAFIA}

Babbie E. (2013), Podstawy badań społecznych. Warszawa: Wydawnictwo Naukowe PWN.

Bajor E., Madej E. (2012), Wśród ludzi i ich spraw. Łódź: Dentonet. Bańko M. (red.) (2013), Polszczyzna na co dzień. Warszawa: PWN.

Ciesielska-M usameh R., Guziuk-Świca B., Przechodzka G. (2018), Z polskim w świat. Lublin: Wydawnictwo UMCS.

Common European Framework of Reference for Languages: Learning, Teaching, Assessment. Companion Volume with New Descriptors (2018), Strasbourg: Council of Europe. Online: https://rm.coe.int/cefr-compani on-volume-with-new-descriptors-2018/1680787989 [DW 27.07.2019]

Dąbrowska A., Miodunka W., Pawłowski A. (2012), Wyzwania polskiej polityki językowej za granicq. Warszawa: M inisterstwo Spraw Zagranicznych.

Dąbrowska A. (2004), Najczęstsze błędy popełniane przez cudzoziemców uczqcych się języka polskiego jako obcego (w) Seretny A., M artyniuk W., Lipińska E. (red.), Opisywanie, rozwijanie i testowanie znajomości języka polskiego jako obcego. Kraków: Universitas, str. 105-136.

Dąbrowska A., Pasieka M. (2005), Koncepcja przewodnika po trudnych miejscach polszczyzny, czyli leksykonu przeznaczonego dla cudzoziemców (w) „Poradnik Językowy", nr 5, str. 22-32.

Europejski system opisu kształcenia językowego: uczenie się, nauczanie, ocenianie (2003), Warszawa: Wydawnictwa CODN.

Gałat E. (2018), Anatomia, język specjalistyczny. Skrypt dla obcokrajow ców na poziomie A2+/B1. Kraków: Wydawnictwo Politechniki Krakowskiej.

Izdebska-Długosz D. (2014), Specyficzne problemy nauczania języka polskiego jako obcego w środowisku ukraińskojęzycznym (w) Gonigroszek D. (red.), Języki obce i kultura: nowe konteksty edukacyjne. Piotrków Trybunalski: Naukowe Wydawnictwo Piotrkowskie, str. 315-323. 
Janowska I. (2017), Mediacja i działania mediacyjne w dydaktyce języków obcych (w) „Języki Obce w Szkole", nr 3, str. 80-86. Online: http://jows.pl/sites/ default/files/jows-3-2017_iwonajanowska.pdf [DW 27.07.2019]

Janowska I., Lipińska E., Rabiej A., Seretny A., Turek P. (red.) (2016), Programy nauczania języka polskiego jako obcego. Poziomy A1-C2. Kraków: Księgarnia Akademicka.

Kaźmierczak J., Gosztowt I. (2012), Podstawy cytologii i genetyki, podręcznik przeznaczony dla słuchaczy Studium Języka Polskiego dla Cudzoziemców. Łódź: Wydawnictwo Uniwersytetu Łódzkiego.

Krawczuk A. (2008), Kłopoty z opanowaniem polskiej rekcji w procesie nauczania Ukraińców sprawności pisania (w) Seretny A., Lipińska E. (red.), Rozwijanie i testowanie biegłości w języku polskim jako obcym. Kraków: Universitas, str. 129-140.

Kugiel-Abuhasna I. (2017), Wybraliśmy ekonomię. Kraków: Wydawnictwo Politechniki Krakowskiej.

Lipińska E., Dąmbska E.G. (2016), Pisać jak z nut. Kraków: Universitas. Martyniuk W. (2018), Działania i strategie mediacyjne w nauczaniu języka polskiego jako obcego (w) Spotkania polonistyk trzech krajów - Chiny, Korea, Japonia, Międzynarodowa Konferencja Akademicka w Seulu, str. 91-102. Mędak S. (2014), Co z czym? Kraków: Universitas.

M iodunka W.T. i in. (2018), Nauczanie i promocja języka polskiego w świecie.

Diagnoza - stan - perspektywy. Katowice: Wydawnictwo Uniwersytetu Śląskiego. Online: http://wydawnictwo.us.edu.pl/sites/ wydawnictwo.us. edu.pl/files/nauczanie_i_promocja_jezyka_polskiego_w_swiecie_intera ktywny_pdf [DW 27.07.2019]

M osiołek-Kłosińska K. (red.) (2014), Formy i normy, czyli poprawna polszczyzna w praktyce. Warszawa: Wydawnictwo Naukowe PWN.

Podsiadło J., LechowiczJ. (2004), Chcę studiować medycynę. Łódź: Wydawnictwo WING. Pyzik J. (2018), Przygoda z gramatykq. Kraków: Universitas.

Rozporzqdzenie M inistra Nauki Szkolnictwa Wyższego z 5 czerwca 2018 w spra-

wie podejmowania przez cudzoziemców studiów i szkoleń oraz ich uczestnictwa w badaniach naukowych i pracach rozwojowych. Online: http:// prawo.sejm.gov.pl/isap.nsf/download.xsp/WDU20180001125/0/D201 81125.pdf [DW 27.07.2019]

Seretny A. (2016), Słownictwo polskiew ćwiczeniach dla obcokrajowców. Kraków: Prolog. Tambor A. (2018), (Nie)codzienny język polski. Katowice: Wydawnictwo Gnome.

Wilczyńska W., Michońska-Stadnik A. (2010), M etodologia badań w glottodydaktyce. Wprowadzenie. Kraków: Avalon.

Wróbel D., Zielińska A., Rudziński G. (2014), M atematyka po polsku. Łódź: Wydawnictwo Uniwersytetu Łódzkiego. 